\title{
Cross-cultural adaptation and validation to Brazil of the Obesity-related Problems Scale
}

\author{
Adaptação transcultural e validação para o Brasil da Obesity-related Problems Scale
}

\author{
Andreia Mara Brolezzi Brasil ${ }^{1}$, Fábio Brasil ${ }^{1}$, Angélica Aparecida Maurício ${ }^{1}$, Regina Maria Vilela ${ }^{1}$
}

\begin{abstract}
Objective: To validate a reliable version of the Obesity-related Problems Scale in Portuguese to use it in Brazil. Methods: The Obesity-related Problems Scale was translated and transculturally adapted. Later it was simultaneously self-applied with a 12-item version of the World Health Organization Disability Assessment Schedule 2.0 (WHODAS 2.0), to 50 obese patients and 50 non-obese individuals, and applied again to half of them after 14 days. Results: The Obesity-related Problems scale was able to differentiate obese from non-obese individuals with higher accuracy than WHODAS 2.0, correlating with this scale and with body mass index. The factor analysis determined a two-dimensional structure, which was confirmed with $\chi^{2} / \mathrm{df}=1.81$, SRMR $=0.05$, and $\mathrm{CFI}=0.97$. The general $\alpha$ coefficient was 0.90 and the inter-item intra-class correlation, in the reapplication, ranged from 0.75 to 0.87 . Conclusion: The scale proved to be valid and reliable for use in the Brazilian population, without the need to exclude items.
\end{abstract}

Keywords: Obesity; Quality of life; Translating; Psychometrics; Validation studies

\section{RESUMO}

Objetivo: Validar uma versão confiável da Obesity-related Problems Scale em português para utilização no Brasil. Métodos: A Obesityrelated Problems Scale foi traduzida e adaptada transculturalmente. Posteriormente, foi autoaplicada simultaneamente à versão de 12 itens da World Health Organization Disability Assessment Schedule 2.0 (WHODAS 2.0) a 50 pacientes obesos e a 50 indivíduos não obesos, sendo reaplicada à metade deles após 14 dias. Resultados: A Obesity-related Problems Scale foi capaz de diferenciar obesos de não obesos com maior acurácia que a WHODAS 2.0, estando correlacionada a esta e com 0 índice de massa corporal. A análise fatorial determinou estrutura bidimensional, que foi confirmada com $\chi^{2} / \mathrm{df}=1,81, \mathrm{SRMR}=0,05$, and $\mathrm{CFI}=0,97.0$ coeficiente $\alpha$ geral foi de 0,90 e a correlação intraclasse interitem, na reaplicação, variou de 0,75 a 0,87. Conclusão: A escala provou ser válida e confiável para ser utilizada na população brasileira, sem necessidade de exclusão de itens.

Descritores: Obesidade; Qualidade de vida; Tradução; Psicometria; Estudos de validação

\section{INTRODUCTION}

In a 39-year analysis in 186 countries, conducted between 1975 and 2014, the prevalence of obesity in adults increased from 3.2 to $10.8 \%$, in males, and from 6.4 to $14.9 \%$, in females. ${ }^{(1)}$ The Brazilian Institute of Geography and Statistics (IBGE - Instituto Brasileiro de Geografia e Estatística) and the Ministry of Health have made available data sufficient for a 41-year analysis: in Brazil, between 1974 and 2015, the prevalence of adult obese men increased from 2.8 to $18.1 \%$; in the case of adult women, this increase went from 8 to $19.7 \% .^{(2,3)}$ Since obesity is classified as a disease, ${ }^{(4)}$ a pandemic is therefore characterized.

The diagnosis of obesity, according to the World Health Organization (WHO), requires a body mass index $(\mathrm{BMI}) \geq 30 \mathrm{~kg} / \mathrm{m}^{2} ;\left(25 \mathrm{~kg} / \mathrm{m}^{2} \leq \mathrm{BMI} \leq 30 \mathrm{~kg} / \mathrm{m}^{2}\right.$, and a BMI $\leq 18.5 \mathrm{~kg} / \mathrm{m}^{2}$ determine overweight and underweight, respectively). ${ }^{(5)}$ Many other diseases present with a direct causal relation to obesity, such as arterial hypertension, dyslipidemia, type 2 diabetes mellitus, coronary artery disease, stroke, biliary lithiasis, hepatic steatosis, osteoarthritis, sleep apnea, cognitive dysfunction,

\footnotetext{
Universidade Federal do Paraná, Curitiba, PR, Brazil.

Corresponding author: Andreia Mara Brolezzi Brasil - Avenida Lothário Meissner, 632 - Jardim Botânico - Zip code: 80210-170 - Curitiba, PR, Brazil - Phone: (55 41) 3360-4010

E-mail: nutrideiabrasil@gmail.com

Received on: Jan 25, 2017-Accepted on: May 16, 2017

Conflict of interest: none.

DOI: 10.1590/S1679-45082017A04004
} 
various types of cancer (colorectal, postmenopausal breast, endometrium, kidney, esophagus, pancreas, and liver), depression, anxiety, and chronic body pain. ${ }^{(6-8)}$ Additionally, obese people are constantly targets of discrimination in all sectors of society, including the job market, education, the media, and even in healthcare which limits their opportunities with generalized negative stereotype comments that they are lazy, disheveled, and less competent, ${ }^{(9)}$ contributing towards a marked decrease in quality of life of this population.

Among the specific psychometric scales to evaluate the impact of obesity on health-related quality of life (HRQoL), those that stand out due to their ample international use, facilitating the conduction of multicenter comparative studies are the Obesityrelated Well-Being (ORWELL 97), ${ }^{(10)}$ the Impact of Weight on Quality of Life (IWQOL-Lite), ${ }^{(11)}$ and the Obesity-related Problem Scale (OP). ${ }^{(12)}$ In this study, the OP was selected because it is the only one of the three that was validated in non-obese people as well, and can be used to measure the HRQoL before and after potentially curative obesity interventions, such as diets and bariatric surgery. ${ }^{(13,14)}$

\section{OBJECTIVE}

To validate a reliable version of the Obesity-related Problems Scale in Portuguese for use in Brazil.

\section{METHODS}

\section{Transcultural adaptation}

The process of transcultural adaptation of the OP was carried out based on systematizations proposed by several authors. ${ }^{(15-17)}$ Two independent translations were made from English to Brazilian Portuguese; the first, by group of three dieticians fluent in English; the second, by a sworn notarized translator, all of them with Brazilian Portuguese as their native language. The translations were independently back-translated into English by two notarized translators who had English as their native language. The back-translations were paired with each other for blinding, and with the original instruments. Then a translator, with English as native language, who had not participated in the previous phase, established an equivalence of to $100 \%$ between the pairs of items.

Three Brazilian dieticians, who did not participate in the previous stages, based on the equivalence established between the items and on their professional experience, drew up, in agreement, a pretest version of OP adapted for Brazilian Portuguese.
Five obese patients were randomly selected, who were patients seen at the outpatient obesity clinic of the Hospital de Clínicas da Universidade Federal do Paraná (UFPR), along with five non-obese employees of UFPR, all of them older than 18 years. The individuals selected answered the pretest version of the OP, as well as their impression as to the clarity and ease of the items.

A psychiatrist, a psychologist, and a dietitian, in agreement, pondered the results of the pretest version and prepared the final version, transculturally adapted for the Brazilian population, of OP (Chart 1). Posteriorly, this version was approved in an analogous pretest, in which no participant reported difficulty in understanding or answering the items.

Chart 1. Brazilian version of the Obesity-related Problems Scale (OP)

OP1. Receber amigos em casa
OP2. Visitar a casa de parentes ou amigos
OP3. Ir a restaurantes
OP4. Fazer atividades na comunidade (cursos etc.)
OP5. Passar férias fora de casa
OP6. Experimentar e comprar roupas
OP7. Banhar-se em locais públicos (praia, piscina etc.)
OP8. Relações íntimas (beijo, sexo etc.)
Os itens da OP estão representados pela sigla "OP" seguida de seu número de ordenamento. Todos eles devem ser respon-
didos em escala Likert da seguinte forma: (1) "Me incomoda muito"; (2) "Me incomoda mais ou menos"; (3) "Me incomoda
um pouco"; e (4) "Não me incomoda".

\section{Study design and subjects}

This is an observational study of quantitative nature carried out in obese and non-obese Brazilians aged over 18 years, during the period from April 28, 2015, to September 29, 2015, in the city of Curitiba (PR).

The transculturally adapted OP was self-applied concurrently with the 12-item version of the World Health Organization Disability Assessment Schedule 2.0 (WHODAS 2.0) $)^{(18)}$ - used as a validation criterion -, in a group of 50 obese patients who did follow-up at the outpatient obesity clinic of Clinics Hospital of the UFPR, and a Control Group, paired by age and sex, of 50 non-obese inhabitants of Curitiba. After 2 weeks, the OP was reapplied to half of the individuals from each group, chosen randomly, but with the proportion maintained between the sexes.

The sample selection was made by convenience, covering all the individuals who met the inclusion criteria until the number of participants needed for the research performance was complete. Excluded were pregnant women, those younger than 18 years, individuals with restrictions in their responsibilities as to autonomy, individuals with visual or hearing problems (reported or 
perceived), and those who did not agree to participate in the investigation or to fill out the Informed Consent Form.

\section{Ethical aspects}

The transcultural adaptation and validation were authorized by the main author of the $\mathrm{OP}^{(12)}$ as well as the dissemination of the version transculturally adapted for Brazilian Portuguese. Using ethical criteria, we chose to work with the minimum number of observations considered ideal for the statistical analysis $(n=100) .{ }^{(19)}$

The research was conducted within the standards required by the Declaration of Helsinki and approved by the UFPR Ethics Committee with CAAE: 38627514.8.0000.0102.

\section{Statistical analysis}

Calculation of the OP scores was done based on the simple sum of the value of each item, using the inverted Likert scale, as per the original study, ${ }^{(12)}$ and its posterior transformation into values between zero to 100; more elevated scores indicated a greater psychosocial commitment and worse HRQOL.

The validity of the convergent criterion was investigated by means of Spearman's correlation coefficients of OP with WHODAS 2.0 and the BMI. It was also verified, through the Mann-Whitney U test (validity of the discriminating criterion), the capacity of the scale to differentiate the following groups: obese, non-obese, men, women, and overweight and normoweight individuals.

Seeking the validity of the construct, an exploratory factor analysis (EFA) was performed using the method of maximum likelihood with oblique matrix rotation by maximal proportions. The number of extracted factors was determined from the analysis of the point of inflection of the scree test. The items that do not present with a minimal communality of 0.4 , with factor extraction, should be considered invalid. ${ }^{(20)}$ Ideally, elevated factor loads should be used in order to frame the items in their respective domains; for this, values over 0.71 were considered excellent. ${ }^{(21)}$

A confirmatory factor analysis (CFA) was performed using the maximum likelihood method. The tested models were unidimensionality, proposed by the original study, ${ }^{(12)}$ and item distribution, suggested by the EFA. For model fit, it was required that the $\chi^{2}$ divided by the number of degrees of freedom $\left(\chi^{2} / \mathrm{df}\right)$ be lower than $3^{(22)}$ and that the comparative fit index (CFI) and the standardized residual root mean square (SRMR) have a value of more than 0.95 and less than 0.08 , respectively, as per recommended for samples smaller than 250 observations. $^{(23)}$ As a complement to CFA, calculation of the internal consistency was required, with a necessary Cronbach coefficient $\alpha \geq 0.7$ in the instrument as a whole, and in each of the individual domains for the validity of the construct to be confirmed. ${ }^{(19)}$

As to reliability, calculation of reproducibility (precision) by means of the intraclass correlation coefficients (ICC), with necessary values of more than 0.7 relative to the two applications of the OP. ${ }^{(19)}$ Responsivity (accuracy) was verified in a comparative manner with WHODAS 2.0, by analysis of the areas under the Receiver Operating Characteristics (ROC) curves. This analysis was possible due to the meticulous pairing between the obese and non-obese individuals, which were confronted.

Calculations were made using the Statistical Package for the Social Sciences software, version 21.0, with extension Analysis of Moment Structures; the level of significance attributed was 0.05 .

\section{RESULTS}

All individuals (80\% women) responded completely to the two instruments, OP and WHODAS 2.0, with no loss of data. The descriptive variables of the study population, including the OP scores, which did not show a normal distribution as per the Kolmogorov-Smirnov test, are exposed on table 1.

The OP scores were capable of differentiating the obese from the non-obese $(U=244 ; z=-6.97 ; p<0.01)$,

Table 1. Sociodemographic, anthropometric variables and Obesity-related Problems Scale scores of the sample population

\begin{tabular}{|c|c|c|c|c|}
\hline Variable & Obese & Non-obese & Women & Men \\
\hline Age $^{*}$, (years) & $44.48(11.70)(18-62)$ & $44.48(11.70)(18-62)$ & $45.50(11.50)(21-62)$ & $40.40(11.57)(18-55)$ \\
\hline Body mass index*, $\left(\mathrm{kg} / \mathrm{m}^{2}\right)$ & $40.42(5.55)(31.64-59.69)$ & $24.05(3.00)(18.50-29.39)$ & $32.30(9.73)(18.36-59.69)$ & $31.97(7.86)(21.67-46.28)$ \\
\hline${ }^{\dagger}$ monthly family income per capita ${ }^{\dagger}$, (Reais) & $827.48(223.14-4462.80)$ & $1000.00(219.44-3750.00)$ & $964.88(219.44-4462.80)$ & $1022.73(219.44-3000.00)$ \\
\hline Years of study ${ }^{\dagger}$ & $11(4-16)$ & $11(4-17)$ & $11(4-17)$ & $11(4-16)$ \\
\hline OP', scale from zero to inverted 100 & $39.58(0.00-100.00)$ & $4.17(0.00-37.50)$ & $20.83(0.00-100.00)$ & $6.25(0.00-41.67)$ \\
\hline
\end{tabular}

* mean; standard deviation and minimal and maximal intervals between parentheses: $\mu(\sigma)$ (min-max); † median; minimal and maximal intervals between parentheses: med (min-max); $n=100(50 \%$ obese; $80 \%$ women). OP: Obesity-related Problems Scale. 
the obese from overweight individuals $(U=76 ; z=-4.46$; $\mathrm{p}<0.01)$, and women from men $(\mathrm{U}=433.5 ; \mathrm{z}=-3.17$; $\mathrm{p}<0.01$ ); nevertheless, they were not able to differentiate overweight individuals from normoweight individuals $(\mathrm{U}=250.5 ; \mathrm{z}=-0.03 ; \mathrm{p}=0.97)$. The OP showed a Spearman correlation coefficient of $0.67(\mathrm{p}<0.01)$ with WHODAS 2.0 and $0.66(\mathrm{p}<0.01)$ with the BMI.

The value of 0.87 was calculated for the KaiserMeyer-Olkin coefficient, which, associated with a sphericity test with a significance of $\mathrm{p}<0.01$, determined that the database was sufficient for the execution of the EFA. The scree test presented with a well-defined inflection point, determining the extraction of two factors (Figure 1), which answered for $78.32 \%$ of the variance; the individual items exhibited satisfactory communalities and factor loads (Table 2).

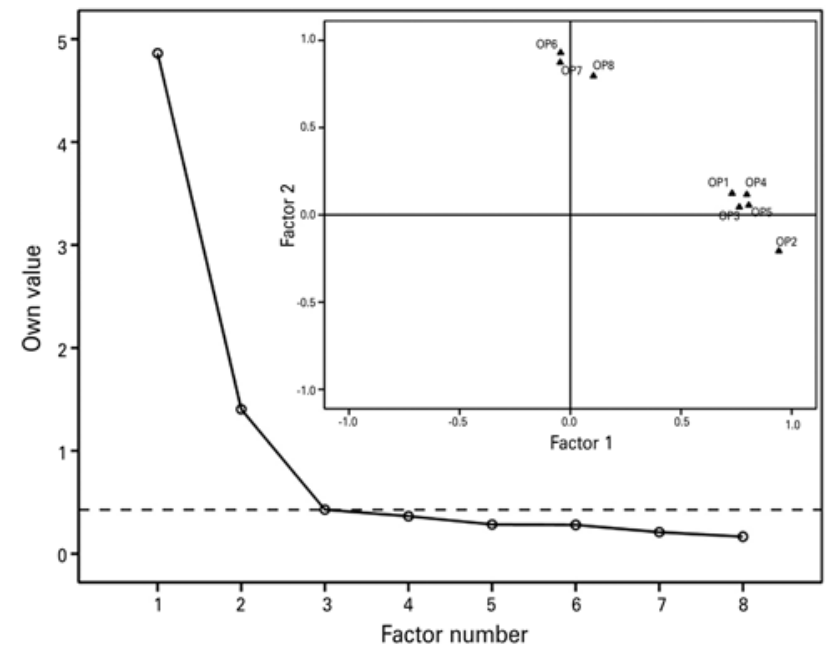

Figure 1. Scree graphs of the factors and of item dispersion of the Obesityrelated Problems Scale. The dashed line crosses the cutoff point used to determine the number of extracted factors; $n=100$ ( $50 \%$ obese; $80 \%$ women)

Table 2. Exploratory factor analysis of the Obesity-related Problems Scale

\begin{tabular}{lccc}
\hline \multirow{2}{*}{ Item } & \multirow{2}{*}{ Communality } & \multicolumn{2}{c}{ Factor loading } \\
\cline { 2 - 4 } & & $\mathbf{6 0 . 7 8 \%}$ & $\mathbf{1 7 . 5 4 \%}$ \\
\hline OP1 & 0.65 & $0.80^{*}$ & 0.54 \\
OP2 & 0.71 & $0.82^{*}$ & 0.33 \\
OP3 & 0.62 & $0.79^{*}$ & 0.48 \\
OP4 & 0.76 & $0.86^{*}$ & 0.57 \\
OP5 & 0.70 & $0.84^{*}$ & 0.51 \\
OP6 & 0.82 & 0.49 & $0.91^{*}$ \\
OP7 & 0.72 & 0.45 & $0.85^{*}$ \\
OP8 & 0.74 & 0.56 & $0.86^{*}$ \\
\hline
\end{tabular}

Extraction by the maximum likelihood method with promax rotation; matrix of the structures. The factors are represented by the percentage of the variance explained.

* relevant factor load; $n=100$ ( $50 \%$ obese; $80 \%$ women).

OP: Obesity-related Problems Scale.
The CFA assessed the hypothesis of a structure with single domain in $\mathrm{OP}$ with the following values for the adjustment indexes: $\chi^{2} / \mathrm{df}=7.70, \mathrm{SRMR}=0.13$ and $\mathrm{CFI}=0.76$. They proved to not be the correct model. When the theoretical structure was tested and the items were divided into two inter-related domains ("sociability" - OP1 to OP5 - and "corporality" - OP6 to OP8 -), we identified $\chi^{2} / \mathrm{df}=1.81$, SRMR $=0.05$ and $\mathrm{CFI}=0.97$, validating this model for the study population.

The $\alpha$ coefficient calculated for the domain "sociability" was 0.91 ; for "corporality," it was 0.90 ; and for the instrument as a whole, it was 0.90 - values sufficient to corroborate the validity of the construct.

The OP demonstrated satisfactory reproducibility between the application and the reapplication, by means of the CCI of 0.93 in reference to the total score. The CCI of the individual items varied from 0.75 to 0.87 .

The area under the ROC curve comparing the group of obese patients and the group of non-obese individuals was $0.74(\mathrm{p}<0.01)$ for the WHODAS 2.0 scale, and $0.90(\mathrm{p}<0.01)$ for the OP, conferring greater accuracy to the latter (Figure 2).

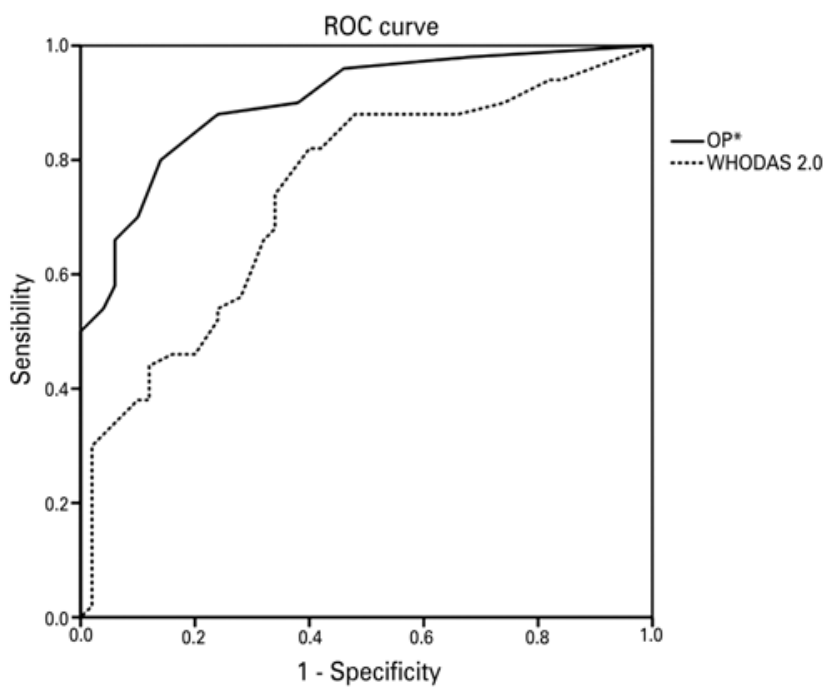

* inverted scale.

ROC: Receiver Operating Characteristics; OP: Obesity-related Problems Scale; WHODAS 2.0: 12-item version of the World Health Organization Disability Assessment Schedule 2.0; $n=50$ ( $50 \%$ obese; 80\% women).

Figure 2. Accuracy in differentiating obese and non-obese

\section{DISCUSSION}

The OP instrument is a scale of outcomes reported by patients, which was developed and validated in Sweden, based on a sample of 12,296 obese and 1,017 non-obese individuals. It primarily measures the impact of excess weight on the psychosocial function; ${ }^{(12)}$ it has been transculturally adapted for Spain, ${ }^{(24)}$ South Korea, ${ }^{(25)}$ and Norway; ${ }^{(14)}$ therefore, its use is corroborated at 
international level and in a large population. The $\alpha$ coefficient, calculated as 0.90 in the present study was similar to that of the original OP instrument ${ }^{(12)}$ and to the adapted versions for Spain, ${ }^{(24)}$ South Korea, ${ }^{(25)}$ and Norway, ${ }^{(14)}$ which presented with $\alpha$ coefficients of $0.89-0.92,0.93$, and 0.91 , respectively, suggesting that there is a general analogy in the psychic construct among the populations. Studies conducted in the abovementioned countries validated the $\mathrm{OP}$ on a single dimension. The present study performed the validation in a two-dimensional manner, as per the results of the CFA, which does not disqualify the validity of the general construct, but merely reflects the presence of its own characteristics in the latent psychological traces of the Brazilian population.

Considering these specific results identified by the CFA in the Brazilian population, the first domain items OP1 to OP5 - was named "sociability", due to the common characteristic of these items to determine latent traces related to the individual's integration with the social group in which they live. ${ }^{(26)}$ A latent trace refers to an intrinsic capacity; thus, the use of the term "sociability" instead of "socialization," which emphasizes an active process; ${ }^{(27)}$ or of "social behavior," which is the product of various "social behaviors," (26) that is, various latent traces. The second domain - items OP6 to OP8 - was called "corporeality," as it characterizes the form in which the brain uses the physical body to relate to the environment, notably, with the social milieu; ${ }^{(28)}$ as opposed to the term "physicality," which is substantially relative to the body, mechanically, and has little psychic denotation. ${ }^{(28)}$

The significant correlation (convergent validity) with the instrument, WHODAS 2.0, which knowingly measures the HRQoL, ${ }^{(18)}$ verified that the instrument OP is also capable of measuring HRQoL. Furthermore, the significant correlation established with the BMI determined that the $\mathrm{OP}$ is endowed with specificity to measure traces associated with body weight and with obesity. ${ }^{(5)}$ The OP may be considered a specific psychometric scale for obesity, capable of measuring HRQOL in a Brazilian population sample.

Attempts were made to discriminate groups (discriminating validity) in order to have an indirect assessment of responsiveness. ${ }^{(19)}$ In this regard, OP proved capable of differentiating obese (patients) from non-obese (healthy) with greater accuracy than the WHODAS 2.0, which is a generic scale of outcomes reported by patients relative to obesity, as was expected in the theoretic proposition. ${ }^{(12)}$ The fact that this instrument does not distinguish people with normal weight from those who are overweight demonstrates the non-discrimination among healthy individuals, since being overweight is not classified as a disease. Additionally, it differentiated between men and women - these with worse scores, as has been systematically verified in patient-reported outcome scales, ${ }^{(29,30)}$ including in the original study. ${ }^{(12)}$ OP was also adequately reproducible, based on the assumption (and even suggesting) that clinical changes were, in fact, negligible between the two applications.

The availability for Brazil of a valid and reliable version of OP fills a gap, based on which the clinical evaluation of the obese patient is no longer restricted to anthropometric, laboratory, and bioimpedance data..$^{(31,32)}$ Now one can approach and measure, by means of the point of view of the persons evaluated, the psychic suffering related to obesity, which is evident but not duly quantified, by the stigmatization of a prejudiced contemporary society, ${ }^{(9)}$ in which the search for the ideal silhouette is an obsession for many. ${ }^{(33)}$

Despite the recommendation of the developers of $\mathrm{OP}$ to consider scores lower than 40 as a mild psychosocial involvement, between 40 and 59 as moderate, and higher than 60 as severe, ${ }^{(12)}$ the interpretation of the scores of the outcome scales reported by patients, based on a more up-to-date view, should not be based on absolute values, but on variations of these scores when establishing an intervention or treatment, determining its efficacy. ${ }^{(34,35)}$ We point out that the OP presents with the advantage of having been validated as well for the non-obese, and can identify disparities in the benefits that different interventions cause in the HRQoL, even when they are effectively curative. After all, it has already been verified that former obese people differ in psychosocial aspects, according to the treatment given to lose weight. ${ }^{(13,36)}$

This study presents the limitation of having been restricted to the population of only one Brazilian city. However, the semantic standardization established as cultured/educated (since as the transcultural adaptation of the OP did not use regional idiomatic expressions), associated with the phenomenon of globalization, both present in Brazil, ${ }^{(37,38)}$ allow the results be nationally acceptable - except in isolated population groups.

Despite having been used successfully in 13 to 18 year-old adolescents, ${ }^{(39)}$ OP presents as an intrinsic limitation the fact of not being appropriate for the pediatric population. Additionally, contrary to the scales of ORWELL-97 and IWQOL-Lite, which also evaluated somatic functional domains, the OP instrument focuses on the psychosocial function, ${ }^{(40)}$ so that the joint application with a scale of patient-reported outcomes directed to measure general function, such as WHODAS 
2.0, becomes imperative for a convincing evaluation of HRQoL.

\section{CONCLUSION}

The Obesity-related Problems Scale proved to be valid and reliable for use in the Brazilian population, both in obese and in non-obese individuals. No item of the instrument needed to be excluded. The transculturally adapted version for Brazil is freely available for research or for clinical practice, and it is not necessary to notify the authors.

\section{ACKNOWLEDGEMENTS}

We would like to thank Dr Jan Karlsson, associate professor of the University of Örebro, in Sweden, who kindly made available the Obesity-related Problems Scale for transcultural adaptation; the employees and patients of the Obesity Outpatient Clinic of the Hospital de Clínicas da Universidade Federal do Paraná; and the volunteers who participated in the Control Group, without whom this study would not have been possible.

\section{REFERENCES}

1. NCD Risk Factor Collaboration (NCD-RisC). Trends in adult body-mass index in 200 countries from 1975 to 2014: a pooled analysis of 1698 populationbased measurement studies with 19.2 million participants. Lancet. 2016; 387(10026):1377-96. Review. Erratum in: Lancet. 2016;387(10032):1998.

2. Brasil. Ministério da Saúde. Ministério do Planejamento, Orçamento e Gestão. Instituto Brasileiro de Geografia e Estatística (IBGE). Diretoria de Pesquisas. Coordenação de Trabalho e Rendimento. Pesquisa de Orçamentos Familiares 2008-2009: antropometria e estado nutricional de crianças, adolescentes e adultos no Brasil [Internet]. Rio de Janeiro (RJ): IBGE; 2010 [citado 2017 Maio 11]. Disponível em: http://biblioteca.ibge.gov.br/visualizacao/livros/ liv45419.pdf

3. Brasil. Ministério da Saúde. Agência Nacional de Saúde Suplementar. Vigitel Brasil 2015 Saúde Suplementar: vigilância de fatores de risco e proteção para doenças crônicas por inquérito telefônico. Estimativas sobre frequência e distribuição sociodemográfica de fatores de risco e proteção para doenças crônicas nas capitais dos 26 estados brasileiros e no Distrito Federal em 2015 [Internet]. Brasília (DF): MS; 2016 [citado 2017 Maio 12]. Disponível em: http://www.ans.gov.br/images/stories/Materiais para pesquisa/Materiais por_assunto/2015_vigitel.pdf

4. World Health Organization (WHO). International Statistical Classification of Diseases and Related Health Problems. 10th Revision (ICD-10) [Internet]. Geneva: WHO; 2016 [cited 2017 May 12]. Available from: http://apps.who. int/classifications/icd10/browse/2016/en

5. Obesity: preventing and managing the global epidemic. Report of a WHO consultation. World Health Organ Tech Rep Ser. 2000;894:i-xii,1-253.

6. Guh DP, Zhang W, Bansback N, Amarsi Z, Birmingham CL, Anis AH. The incidence of co-morbidities related to obesity and overweight: a systematic review and meta-analysis. BMC Public Health. 2009;9:88. Review.

7. Mitchell NS, Catenacci VA, Wyatt HR, Hill JO. Obesity: overview of an epidemic. Psychiatr Clin North Am. 2011;34(4):717-32. Review.
8. Arnold M, Leitzmann M, Freisling H, Bray F, Romieu I, Renehan A, et al. Obesity and cancer: an update of the global impact. Cancer Epidemiol. 2016;41:8-15 Review.

9. Jackson SE. Obesity, weight stigma and discrimination. J Obes Eat Disord 2016;2(1):1-3.

10. Mannucci E, Ricca V, Barciulli E, Di Bernardo M, Travaglini R, Cabras PL, et al. Quality of life and overweight: the obesity related well-being (orwell 97) questionnaire. Addict Behav. 1999;24(3):345-57.

11. Kolotkin RL, Crossby RD, Kosloski KD, Williams GR. Development of a brief measure to assess quality of life in obesity. Obes Res. 2001;9(2):102-11.

12. Karlsson J, Taft C, Sjöström L, Torgerson JS, Sullivan M. Psychosocial functioning in the obese before and after weight reduction: construct validity and responsiveness of the Obesity-related Problems scale. Int J Obes Relat Metab Disord. 2003;27(5):617-30.

13. Karlsson J, Taft C, Rydén A, Sjöström L, Sullivan M. Ten-year trends in healthrelated quality of life after surgical and conventional treatment for severe obesity: the SOS intervention study. Int J Obes (Lond). 2007;31 (8):1248-61.

14. Aasprang A, Andersen JR, Våge V, Kolotkin RL, Natvig GK. Psychosocial functioning before and after surgical treatment for morbid obesity: reliability and validation of the Norwegian version of obesity-related problem scale. PeerJ. 2015;3:e1275. eCollection 2015.

15. Beaton DE, Bombardier C, Guillemin F, Ferraz MB. Guidelines for the process of cross-cultural adaptation of self-report measures. Spine (Phila Pa 1976). 2000;25(24):3186-91. Review.

16. Wild D, Grove A, Martin M, Eremenco S, McElroy S, Verjee-Lorenz A, Erikson P. ISPOR Task Force for Translation and Cultural Adaptation. Principles of Good Practice for the Translation and Cultural Adaptation Process for PatientReported Outcomes (PRO) Measures: report of the ISPOR Task Force for Translation and Cultural Adaptation. Value Health. 2005;8(2):94-104.

17. Sousa VD, Rojjanasrirat W. Translation, adaptation and validation of instruments or scales for use in cross-cultural health care research: a clear and userfriendly guideline. J Eval Clin Pract. 2011;17(2):268-74.

18. Castro SS, Leite CF, editores. Avaliação de Saúde e Deficiência. Manual do WHO Disability Assessment Schedule (WHODAS 2.0). Traduzido por Osterbrock C Santos MT, Adery R. Uberaba: Universidade Federal do Triângulo Mineiro; 2015.

19. Terwee CB, Bot SD, de Boer MR, van der Windt DA, Knol DL, Dekker J, et al. Quality criteria were proposed for measurement properties of health status questionnaires. J Clin Epidemiol. 2007;60(1):34-42.

20. Costello $A B$, Osborne JW. Best practices in exploratory factor analysis: four recommendations for getting the most from your analysis. Pract Assess Res Eval. 2005;10(7):1-9

21. Comrey AL, Lee HB. A first course in factor analysis. 2nd ed. New Jersey: Lawrence Erlbaum Associates; 1992.

22. Drasgow F, Levine MV, Tsien S, Williams B, Mead AD. Fitting polytomous item response theory models to multiple-choice tests. Appl Psychol Meas. 1995;19(2):143-66

23. Hu LT, Bentler PM. Cutoff criteria for fit indexes in covariance structure analysis: conventional criteria versus new alternatives. Struct Equation Modeling: a Multidisciplin J. 1999;6(1):1-55

24. Bilbao A, Mar J, Mar B, Arrospide A, Martínez de Aragón G, Quintana JM Validation of the Spanish translation of the questionnaire for the obesity-related problems scale. Obes Surg. 2009;19(10):1393-400.

25. Lee YJ, Moon KH, Choi JH, Cho MJ, Shin SH, Heo Y. Validation of the Korean translation of obesity-related problems scale assessing the quality of life in obese Korean. J Korean Surg Soc. 2013;84(3):140-53.

26. McCallum C. Alteridade e sociabilidade kaxinauá: perspectivas de uma antropologia da vida diária. Rev Bras Cienc Soc. 1998;13(38):127-36.

27. Setton MG. A particularidade do processo de socialização contemporâneo. Rev Tempo Soc. 2005;17(2):335-50.

28. Soares MG, Kaneko GL, Gleyse J. Do porto ao palco, um estudo dos conceitos de corporeidade e corporalidade. Dialektiké. 2015;3(1):66-75

29. Ciconelli RM, Ferraz MB, Santos W, Meinão I, Quaresma MR. [BrazilianPortuguese version of the SF-36. A reliable and valid quality of life outcome measure]. Rev Bras Reumatol. 1999;39(3):143-50. Portuguese. 
30. Brasil F, Brasil AM, Souza RA, Pontarolo R, Correr CJ. [Development of the Brazilian brief version of the Diabetes Quality of Life Measure (DQOL-Brazil-8)]. Rev Bras Epidemiol. 2015;18(4):943-52. Portuguese.

31. Lukaski HC. Evolution of bioimpedance: a circuitous journey from estimation of physiological function to assessment of body composition and a return to clinical research. Eur J Clin Nutr. 2013;67(1):S2-9.

32. Yumuk V, Tsigos C, Fried M, Schindler K, Busetto L, Micic D, Toplak H; Obesity Management Task Force of the European Association for the Study of Obesity. European Guidelines for Obesity Management in Adults. Obes Facts. 2015;8(6)402-24. Erratum in: Obes Facts. 2016;9(1):64.

33. Lewer M, Nasrawi $N$, Schroeder D, Vocks S. Body image disturbance in binge eating disorder: a comparison of obese patients with and without binge eating disorder regarding the cognitive, behavioral and perceptual component of body image. Eat Weight Disord. 2016;21(1):115-25.

34. Revicki D, Hays RD, Cella D, Sloan J. Recommended methods for determining responsiveness and minimally important differences for patient-reported outcomes. J Clin Epidemiol. 2008;61 (2):102-9. Review.
35. Brasil F, Pontarolo R, Correr CJ. Patient reported outcomes measures (PROMs) in diabetes: why are they still rarely used in clinical routine? Diabetes Res Clin Pract. 2012;97(1):e4-5.

36. Ahnis A, Figura A, Hofmann T, Stengel A, Elbelt U, Klapp BF. Surgically and conservatively treated obese patients differ in psychological factors, regardless of body mass index or obesity-related co-morbidities: a comparison between groups and an analysis of predictors. PLoS One. 2015;10(2):e117460. eCollection 2015.

37. Savedra MM, Lagares XC. Política e planificação linguística: conceitos, terminologias e intervenções no Brasil. Gragoatá. 2012;17(32):11-27.

38. Jesus JG. [Psychology of masses: context and brazilian challenges]. Psicol Soc. 2013;25(3):493-503. Portuguese.

39. Järvholm K, Karlsson J, Olbers T, Peltonen M, Marcus C, Dahlgren J, et al. Two-year trends in psychological outcomes after gastric bypass in adolescents with severe obesity. Obesity (Silver Spring). 2015;23(10):1966-72.

40. Vallis M. Quality of life and psychological well-being in obesity management: improving the odds of sucess by managing distress. Int J Clin Pract. 2016; 70(3):196-205. Review. 